\title{
The Shortest Peroxidase Stain Time and the Mean Cellular Peroxidase Content of Blood Leukocytes*
}

\author{
Ototaka Higashi $\uparrow$ \\ Department of Pediatrics (Prof. H. Wako), Iwate Medical College, \\ Morioka and Department of Pediatrics (Prof. Ts. Arakawa), \\ Faculty of Medicine, Tohoku University, Sendai
}

A new modification of the shortest peroxidase stain time (SPST) method for blood leukocytes, originally studied by Suzuki, based on the Sato-Sekiya's stain, was described. This method can be used for a quantitative determination of the peroxidase activity of leukocytes. The rationale of the method was demonstrated.

The mean cellular peroxidase content (MCP) of myelogenous leukocytes of ten hospitalized patients estimated by the present SPST method, was equivalent, in average, to $(15.29 \pm 3.71) \times 10^{-8} \gamma$ of horseradish peroxidase (HRP) in eosinophils, $(8.18 \pm 4.08) \times 10^{-8} \gamma$ of HRP in neutrophils and $(4.97 \pm 2.72) \times 10^{-8} \gamma$ of HRP in monocytes, respectively.

The copper peroxidase reaction method was originally devised by Sato and Sekiya for the purpose of differentiating between myelogenous and lymphatic cells. ${ }^{10,21,24,38}$ It became soon apparent that the peroxidase activity was likely to be essential for a normal life process as suggested by the observation of the loss of this enzyme activity in cases of encephalitis lethalgica (Economo type). ${ }^{22,23}$ Since then, some quantitative alterations of peroxidase activity of leukocytes, estimated by the use of modifications of Sato-Sekiya's original method, i.e., the shortest peroxidase stain time (SPST) method ${ }^{6,7,32-34}$ and the counting chamber method,,$^{11,25}$ have been studied in their laboratory and others. ${ }^{28}$

The purpose of the present paper is to describe a new method for the SPST test, by which the beginning reactivity of peroxidase of individual blood cell under carefully standardized conditions of Sato-Sekiya's peroxidase stain, or the shortest time (in seconds) during which a neutrophil, a monocyte or an eosinophil has begun to take peroxidase stain, can be estimated more accurately than by the original method. The rationale of the method was demonstrated by experiments. And it was shown that the cellular peroxidase content in gravimetric units of a peroxidase preparation could be estimated on the basis of SPST of these leukocytes.

Received for publication, February 14, 1966.

* Read at the 67th Meeting of Japan Pediatric Society, held in Sapporo, June 19, 1964 and also at the 19th Meeting of the Tohoku Hematological Society, held in Sendai, February 21, 1965.

+ Present adress: Department of Pediatrics, Faculty of Medicine, Tohoku University, Sendai 


\section{MATERIALS AND METHODS}

Capillary blood was taken either from ear lobe, finger, toe or sole. Blood smears were prepared by the cover glass technic and were air-dried well. The cover glass of $18 \times 18 \mathrm{~mm},{ }^{2}$ in size was used. A large number, at least thirty, of blood smears were prepared from each patient, so that a good homogeneous smear, neither too thick nor too thin, might be chosen out of them. Blood smears were tested within a definite time, always within four hours after blood taking. The reaction was tested always at the room temperature.

Reagents The reagents of Sato-Sekiya's copper peroxidase stain were used with a slight modification.

Solution A: Copper sulfate solution. $\mathrm{CuSO}_{4} \cdot 5 \mathrm{H}_{2} \mathrm{O} 0.1 \mathrm{~g}$., $\mathrm{NaCl} 0.75$ g., distilled water $100 \mathrm{ml}$.

The copper sulfate solution in the present method is more diluted than in the original method to slow down the reaction process. Sodium chloride is added in order to adjust the ionic strength of the solution.

Solution B: Benzidine peroxide solution. Rub $0.5 \mathrm{~g}$ of benzidine base in a mortar with a few drops of water. Add $500 \mathrm{ml}$ of water and filter. Then add $0.5 \mathrm{ml}$ of $3 \%$ hydrogen peroxide to the filtrate. Keep in brown bottle. It is advisable to prepare solution $B$ fresh once a week for the purpose of the present test.

Solution C: $1 \%$ aqueous safranin-0 solution for counter stain.

Technic Apply $0.3 \mathrm{ml}$ of solution A on to a fresh air-dried blood smear for one minute. (Do not pour it off.) Then add $0.1 \mathrm{ml}$ of solution $\mathrm{C}$ and wait for five minutes. (Do not pour it off.) Then add $0.5 \mathrm{ml}$ of solution $\mathrm{B}$ to the mixture above described, timed by use of a metronome. When a definite time (seconds) has elapsed, wash the staining solutions off thoroughly with running water. The smears, thus stained, are air-dried and examined microseopically with oilimmersion. A magnification $7 \times 100$ is used.

How to record the results of SPST tests? There is a range of the peroxidase reacting time, usually from one to ten seconds, during which the peroxidase reaction is allowed to proceed. One hundred consecutive blood neutrophils, for example, on each smear were examined under microscope with oil immersion to determine the percentage of peroxidase-positive cells. Here the peroxidasepositive cell was such a one as had first taken peroxidase stain, regardless of the size of peroxidase granule, either solitary or in group (cf. Fig. 1). The SPST curve was constructed by plotting on graph paper the percentage of peroxidasepositive cells on each smear against the corresponding peroxidase reacting time (cf. Fig. 2). In the early stage of the present investigation, the results of SPST tests were recorded as the SPST curves. But, as the study progressed, it became clear that the SPST could be converted into gravimetric units of the enzyme. 


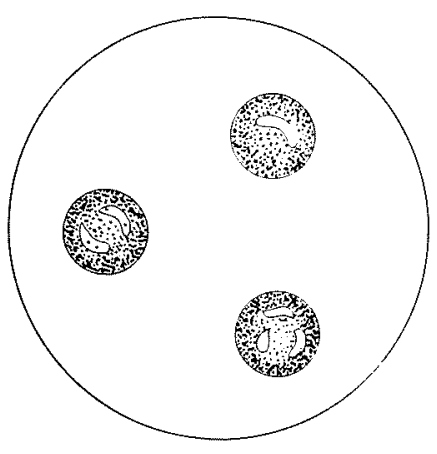

A

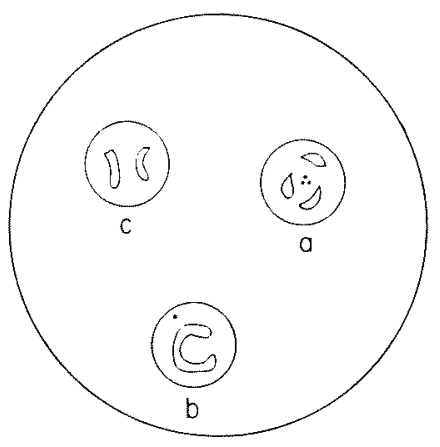

B

Fig. 1. A: Blood neutrophils stained with the original method of Sato-Sekiya's peroxidase stain. All the cells are loaded with a great number of peroxidase granules.

B: Blood neutrophils stained with the present SPST method, showing the beginning reactivity of peroxidase of the cells. The cells $a$ and $b$, peroxidasepositive forms, have few peroxidase granules, while the cell c, a peroxidasenegative form, has no peroxidase granule at all.

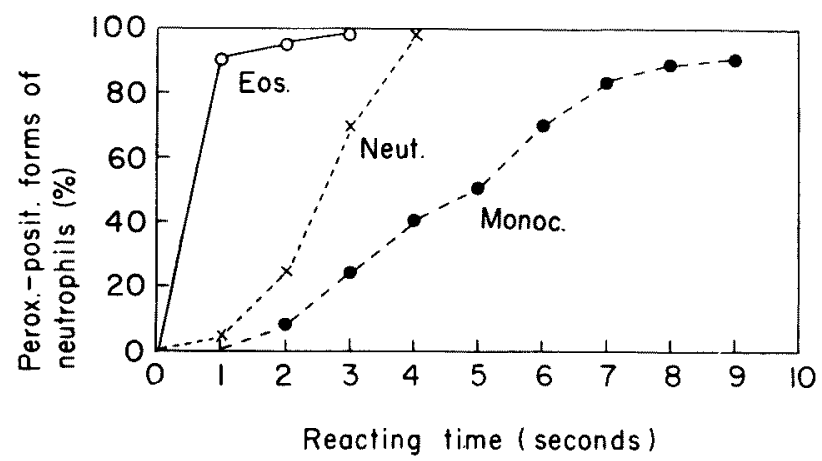

Fig. 2. The SPST curves of blood eosinophils (Eos.), neutrophils (Neut.) and monocytes (Monoc.). Note the difference of SPST curves among various kinds of leukocytes. The blood was drawn from a 15-year-old boy, case No. 102 in Table 4 (of. Table 4), who was under thyroid medication for his hypothyroidism, in a heparinized syringe. Smears were prepared from the buffy coat after centrifugation.

And thence, the results of SPST tests were recorded as the mean cellular peroxidase content (MCP) of each type of myelogenous leukocytes, in the way which will be described in the present paper.

N.B. Any student can try the original Sato-Sekiya's peroxidase stain with success within a few hours of his trial, but the present SPST method is technically much more difficult and it may take one a mouth or so to master it.

Not infrequently, the cells near the edges of a blood smear may, for some unknown reason, show a more or less prolonged SPST than the cells in the central parts. So it 
is better to examine the cells in the central parts of a smear.

It is preferable to complete the microscopic examination of stained films within a few days after staining, though the peroxidase stain usually remains unchanged for a week or longer, if stained smears were kept at room temperature in a covered box.

\section{The SPSTs of peroxidase solution in known concentrations}

1. The effect of the concentration of horseradish peroxidase on the reaction between solutions A (copper sulfate) and B (benzidine and hydrogen peroxide): The following experiment was performed to see the effect of peroxidase on the reaction between solutions $A$ and $B$.

About $0.004 \mathrm{ml}$ of (water or enzyme added) solution A (mixture of three parts of $0.1 \%$ copper sulfate, i.e., solution $A$, and one part of water or aqueous solution of peroxidase,* 500 to $10 \gamma / \mathrm{ml}$ ) and about $0.005 \mathrm{ml}$ of solution B were placed apart on the glass surface of a counting chamber or a tissue culture slide. $\dagger$

TABLE 1. The determination of SPSTs of horseradish peroxidase (HRP) solutions in known concentrations

\begin{tabular}{|c|c|c|c|c|}
\hline \multicolumn{4}{|c|}{ Solution A } & \multirow[b]{3}{*}{ Mean in seconds } \\
\hline \multicolumn{2}{|c|}{ Enzyme (H.R.P.) solution } & \multirow[b]{2}{*}{$\begin{array}{c}\text { Water } \\
\mathrm{ml}\end{array}$} & \multirow{2}{*}{$\begin{array}{c}0.1 \% \\
\text { Copper } \\
\text { sulfate } \\
\text { solution } \\
\mathrm{ml}\end{array}$} & \\
\hline $\begin{array}{l}\text { Concentration } \\
\qquad \gamma / \mathrm{ml}\end{array}$ & $\begin{array}{c}\text { Amount } \\
\mathrm{ml}\end{array}$ & & & \\
\hline $\begin{array}{r}500 \\
200 \\
100 \\
50 \\
30 \\
20 \\
10\end{array}$ & $\begin{array}{l}0.1 \\
0.1 \\
0.1 \\
0.1 \\
0.1 \\
0.1 \\
0.1 \\
0\end{array}$ & $\begin{array}{l}0 \\
0 \\
0 \\
0 \\
0 \\
0 \\
0 \\
0.1\end{array}$ & $\begin{array}{l}0.3 \\
0.3 \\
0.3 \\
0.3 \\
0.3 \\
0.3 \\
0.3 \\
0.3\end{array}$ & $\begin{array}{r}1.0 \pm 0.1 \\
2.3 \pm 0.2 \\
3.4 \pm 0.3 \\
5.3 \pm 0.5 \\
8.5 \pm 0.7 \\
10.8 \pm 0.8 \\
15.9 \pm 0.9 \\
140.0 \pm 10.0\end{array}$ \\
\hline
\end{tabular}

* At least three determinations of the SPST were made for each concentration of the enzyme solution.

The reaction mixture contained approximately $0.004 \mathrm{ml}$ of solution $A$ and 0.005 $\mathrm{ml}$ of solution $\mathrm{B}$ (benzidine and hydrogen peroxide).

The cover glass was next placed on the chamber. The slide was examined under a microscope (not with the oil immersion in this case) with a magnification of $7 \times 10$ or $7 \times 20$. When two drops of solutions $A$ and $B$ came into contact and both solutions were partly mixed, a stop watch was started and the time required by the mixture to develop any blue precipitate, recognizable under the microscope, was measured. The results were summarized in Table 1 and Fig. 3.

* Horseradish peroxidase (Nutritional Biochemical Co., Cleveland, Ohio, USA) was used. $\dagger$ Hiraki's tissue culture slide, No. 1, depth $0.2 \mathrm{~mm}$, Nihonrinshokikai Co., Tokyo, was
used. 


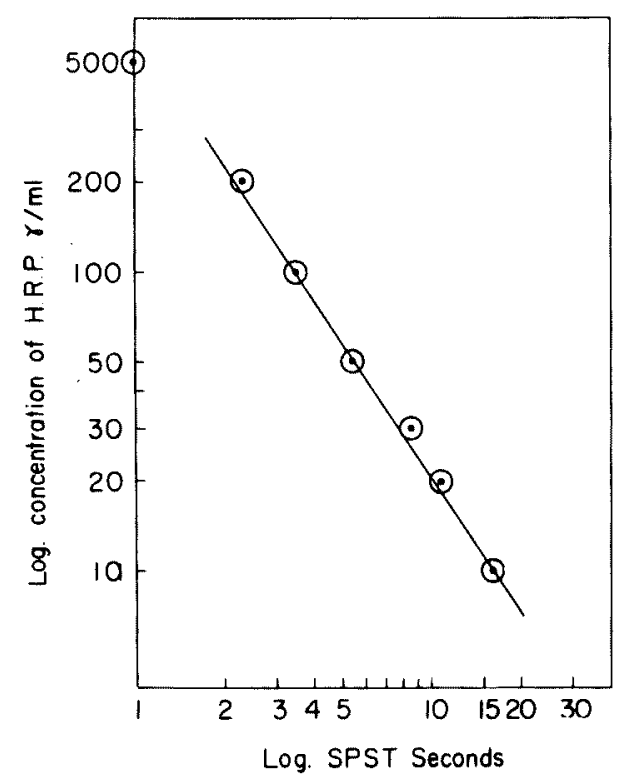

Fig. 3. The relationship between the concentration of enzyme (HRP) solution and the SPST.

With this technic, the time required by the mixture, at the site of contact of solution A (containing no peroxidase) and solution $B$, to develop any blue precipitate was prolonged to even 140 seconds or more. But, in the presence of peroxidase in solution A, the time was greatly shortened, i.e., up to 1 second or less (cf. Fig. 3). And the time required by the reaction mixture of solutions $A$ and $B$ to begin to develop any blue precipitate (at the site of contact of both solutions) could be correlated with the concentration of peroxidase in solution A (cf. Fig. 3).

In a parallel study with the same technic as described above, it was shown that, in the absence of copper sulfate, peroxidase reacted with solution B to develop brown precipitates, but no blue precipitates were produced, unless much higher concentrations of peroxidase were employed.

2. The effect of the concentration of myeloperoxidase on the reaction between solutions A and B: Myeloperoxidase could substitute horseradish peroxidase in the oxidation of benzidine under the conditions of the method employed in Fig. 3. The myeloperoxidase solution used in the present experiments was prepared from canine leukocytes by the method of Agner ${ }^{1,2}$ and had ratios absorbancy 430/ absorbancy 280 of 0.62 and absorbancy $430 / a b s o r b a n c y ~ 390$ of 1.62 and its optical density at $430 \mathrm{~m} \mu$ was 0.22 . The effect of the concentration of myeloperoxidase (MPO) on the reaction between solutions A and B is shown in terms of SPST in Table 2 and Fig. 4. (cf. Table 2 and Fig. 4). 
TABLE 2. The determination of SPSTs of myeloperoxidase (MPO) solutions at various concentrations*

\begin{tabular}{|c|c|c|c|c|}
\hline \multicolumn{4}{|c|}{ Solution A } & \multirow{2}{*}{ SPST $†$} \\
\hline \multicolumn{2}{|c|}{ MPO solution } & \multirow{2}{*}{ Water } & \multirow{2}{*}{$\begin{array}{c}0.1 \% \\
\text { Copper } \\
\text { sulfate } \\
\text { solution } \\
\text { ml }\end{array}$} & \\
\hline $\begin{array}{l}\text { Concentration, } \\
\% \text { of original } \\
\text { solution }\end{array}$ & $\begin{array}{c}\text { Amount } \\
\text { ml }\end{array}$ & & & Mean in seconds \\
\hline 100.6 & 0.1 & 0 & 0.3 & $7.0 \pm 0.5$ \\
\hline $75 \%$ & 0.1 & 0 & 0.3 & $9.5 \pm 0.7$ \\
\hline $50 \%$ & 0.1 & 0 & 0.3 & $12.6 \pm 2.6$ \\
\hline 3096 & 0.1 & 0 & 0.3 & $21.4 \pm 2.1$ \\
\hline $20 \%$ & 0.1 & 0 & 0.3 & $24.0 \pm 3.0$ \\
\hline $10 \%$ & 0.1 & 0 & 0.3 & $45.0 \pm 5.0$ \\
\hline $5 \%$ & 0.1 & 0 & 0.3 & $86.5 \pm 6.5$ \\
\hline & 0 & 0.1 & 0.3 & $145.0 \pm 10.0$ \\
\hline $100 \%$ & 0.1 & 0.3 & 0 & $17.0 \pm 3.0_{+}^{+}$ \\
\hline
\end{tabular}

* The canine leukocyte myeloperoxidase (MPO), prepared by the method of Agner,,$_{, 2}$ was used. The preparation had A430/A280 ratio of 0.62 and A430/A390 ratio of 1.62 , and its optical density at $430 \mathrm{~m} \mu$ was 0.22 . This preparation was dissolved in water and used as a $100 \%$ enzyme solution. Dilution of the enzyme solution was made with distilled water.

+ At least three determinations of the SPST were made for each concentration of the enzyme solution. The reaction mixture contained approximately 0.004 $\mathrm{ml}$ of solution $\mathrm{A}$ and $0.005 \mathrm{ml}$ of solution $\mathrm{B}$ (benzidine and hydrogen peroxide).

: Brown precipitates, instead of blue precipitates, developed at the time shown in the table.

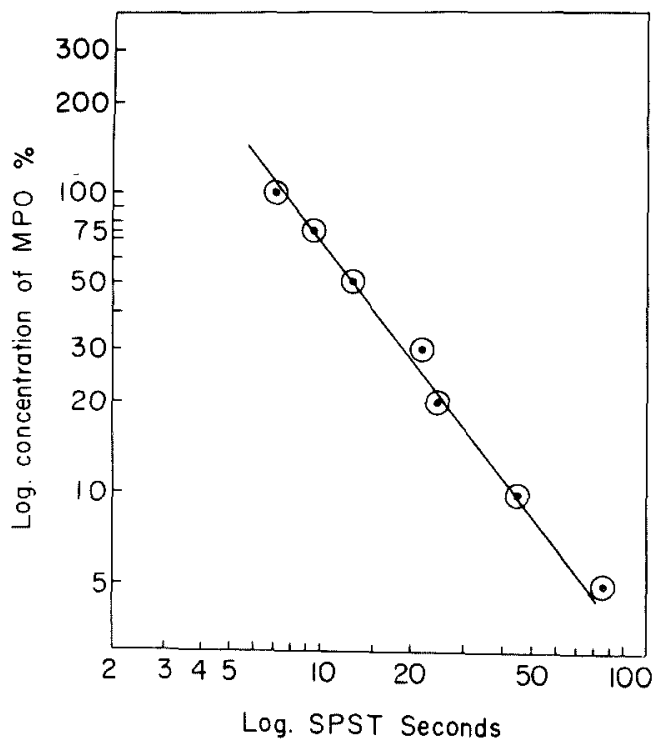

Fig. 4. The relationship between the concentration of enzyme (MPO) solution and the SPST. 
The results of above described observations support the view that the present SPST method is rational and the SPST of blood leukocytes can reflect, to some extent, the concentration of peroxidase in the cells. It is needless to add that blood leukocytes are not homogeneous in their structure. They contain, in addition to peroxidase itself, other substances, which may influence the peroxidase activity in some way or other, as will be discussed later.

Conversion of SPST to gravimetric units of horseradish peroxidase (cf. Table 3):

When the SPSTs, determined as shown in Table 1, were plotted against the concentration of horseradish peroxidase (HRP) on a $\log / \log$ scale, a linear relation was obtained (cf. Fig. 3). Under standard conditions, this relation can be used to convert SPSTs into gravimetric units of peroxidase (HRP) as equivalents of myeloperoxidase activity in the cell, assuming that the mean cellular volumes of neutrophils and monocytes are 450 cu $\mu$ and $470 \mathrm{cu} \mu$ respectively on the basis of the data reported ${ }^{36}$ (cf. Table 3).

TABLE 3. The table for conversion of SPST to gravimetric units of HRP

\begin{tabular}{|c|c|c|c|c|}
\hline $\begin{array}{l}\text { SPST } \\
\text { sec }\end{array}$ & $\begin{array}{l}\text { HRP conc. } \\
\qquad \gamma / \mathrm{ml}\end{array}$ & $\begin{array}{c}\text { For neutrophils } \\
\text { and eosinophils, } \\
\text { HRP } \\
\gamma / 450 \mathrm{cu} \mu\end{array}$ & \multicolumn{2}{|c|}{$\begin{array}{c}\text { For monocytes, } \\
\text { HRP } \\
\gamma / 470 \mathrm{cu} \mu\end{array}$} \\
\hline $1^{\prime \prime}$ & 500 & $22.50 \times 10^{-8}$ & 23.50 & $10^{-8}$ \\
\hline $2^{\prime \prime}$ & 230 & 10.35 & 10.81 & " \\
\hline $3^{\prime \prime}$ & 130 & $5.85 \prime \prime$ & 6.11 & $"$ \\
\hline $4^{\prime \prime}$ & 70 & $3.15 \|$ & 3.29 & $"$ \\
\hline $5^{\prime \prime}$ & 58 & $2.61 " \prime$ & 2.73 & $"$ \\
\hline $6^{\prime \prime}$ & 45 & 2.03 & 2.12 & $"$ \\
\hline $7^{\prime \prime}$ & 35 & 1.58 & 1.65 & $"$ \\
\hline $8^{\prime \prime}$ & 28 & 1.26 & 1.32 & $"$ \\
\hline $9^{\prime \prime}$ & 24 & 1.08 & 1.13 & $"$ \\
\hline $10^{\prime \prime}$ & 20 & 0.90 & 0.94 & $"$ \\
\hline $11^{\prime \prime}$ & 17 & 0.77 & 0.80 & $"$ \\
\hline $12^{\prime \prime}$ & 15 & $0.68 "$ & 0.71 & $"$ \\
\hline $13^{\prime \prime}$ & 13 & 0.59 & 0.61 & $" \prime$ \\
\hline $14^{\prime \prime}$ & 12 & 0.54 & 0.56 & $"$ \\
\hline $15^{\prime \prime}$ & 11 & $0.50 \quad " l$ & 0.52 & $"$ \\
\hline $16^{\prime \prime}$ & 10 & 0.45 & 0.47 & $"$ \\
\hline $17^{\prime \prime}$ & 9 & 0.41 & 0.42 & $"$ \\
\hline $18^{\prime \prime}$ & 8 & $0.36 "$ & 0.38 & $" \prime$ \\
\hline $19^{\prime \prime}$ & 7.5 & 0.34 " & 0.35 & $"$ \\
\hline $20^{\prime \prime}$ & 7 & $0.32 "$ & 0.33 & $" r$ \\
\hline
\end{tabular}

For example, if the SPST of a neutrophil is three seconds, the peroxidase activity of the cell, determined from the standard curve in Fig. 3, would be equivalent to that of enzyme solution containing $130 \gamma \mathrm{HRP}$ per $\mathrm{ml}$, (or $5.85 \times$ $10^{-8} \gamma$ of HRP per $450 \mathrm{cu} \mu$ ). The peroxidase content of the neutrophil may thus be calculated as equivalent to $5.85 \times 10^{-8} \gamma$ of HRP. 
The mean cellular peroxidase content

Multiply each amount of the enzyme (in $\gamma$ of HRP) by the number (in percentage) of cells found with that amount of enzyme, add all the products, and divide by the total number (in per cent) of cells counted.

Sample calculations:

1. If the totals of peroxidase-positive forms of neutrophils at each reaction time are $5 \%$ at 1 sec, $25 \%$ at 2 sec, $71 \%$ at 3 sec and $100 \%$ at 4 sec, respectively under the present standard method, then the mean cellular peroxidase activity (MCP) can be calculated as follows.

MCP of the neutrophils, in $10^{-8} \times \gamma$ of HRP $=[(22.50 \times 5)+\{10.35 \times(25-5)\}$ $+\{5.85 \times(71-25)\}+\{3.15 \times(100-71)\}] \div 100=6.80$

2. If the totals of peroxidase-positive forms of monocytes at each reaction time are $0 \%$ at $1 \mathrm{sec}, 9 \%$ at $2 \mathrm{sec}, 25 \%$ at $3 \mathrm{sec}, 41 \%$ at 4 sec, $51 \%$ at 5 sec, $71 \%$ at $6 \mathrm{sec}, 84 \%$ at $7 \mathrm{sec}, 89 \%$ at $8 \mathrm{sec}$, and $91 \%$ at $9 \mathrm{sec}$ respectively under the present standard method, then the mean cellular peroxidase activity (MCP) can be calculated as follows.

MCP of monocytes, which became peroxidase-positive within 9 sec of reaction time, in $10^{-8} \times \gamma$ of $\mathrm{HRP}=[(10.81 \times 9)+\{6.11 \times(25-9)\}+\{3.29 \times(41-25)\}+$ $\{2.73 \times(51-41)\}+\{2.12 \times(71-51)\}+\{1.65 \times(84-71)\}+\{1.32 \times(89-84)\}+\{1.13 \times$ $(91-89)\}] \div 91=347.70 \div 91=3.82$

MCP of monocytes may thus be expressed as equivalent to $3.82 \times 10^{-8} \gamma$ of HRP or less. If the maximum peroxidase-positivity* is known, then the MCP of monocytes as a whole may be determined more accurately. MCP of monocytes as a whole, namely, including both peroxidase-positive and peroxidase-negative forms, may be calculated as follows, assuming that the percentage of peroxidasepositive forms of monocytes reached the maximum value, ${ }^{*}$ for example $97 \%$ at 10 sec of the reaction time.

MCP of monocytes as a whole, in $\times 10^{-8} \gamma$ of $\mathrm{HRP}=[347.70+\{0.94 \times(97-$ 91) $\}] \div 100=3.53$

As described already, the shortest time required to develop any blue granules (SPST) in the reaction mixture containing enzyme preparation of known concentration was measured by the microscopic observation, in which lower magnification was used for the sake of convenience than in the case of determination of SPST of leukocytes in blood smear. Therefore, the actual peroxidase content of leukocytes would be less than the value obtained from the above table (Table 3), although there will be a parallel relation between these two values.

Notwithstanding such drawback or uncertainty, the present SPST method

* The maximum peroxidase-positivity of monoeyte is defined as the maximum percentage of peroxidase-positive forms of monocytes determined under the Sato-Sekiya's original
method. 
is still the most useful method at present for the determination of peroxidase activity of leukocytes, because this method has the advantage of evaluating the enzyme activity of leukocytes 'individually' under the microscope.

\section{RESULTS}

By the use of the present method, it is possible to determine the SPSTs of neutrophils, eosinophils and monocytes, respectively. An example is illustrated in Fig. 2. In general, the SPST of eosinophils is much shorter and that of monocytes is much longer than that of neutrophils, as might be expected.

The individual cells, even among the same kind of granulocytes, differed in SPST slightly from one other. Normally, some neutrophils, for example, of a smear begin to take stain a few seconds earlier or later than the majority of population. During the first one to two seconds, neutrophils seem to take stain rather reluctantly, but then, in the following one to two seconds, they will take stain rapidly, so that now the majority of neutrophils have begun to take stain. A steep slope of SPST curve (cf. Fig. 2) was thus formed usually between the first two and four seconds of the stain time. A few cells per hundred neutrophils, however, may require one to two seconds more to take their first stain. So the above-mentioned slope may be followed by a gentle slope ending at five or six seconds of the reacting time.

As described already, these SPSTs can be converted into gravimetric units of HRP, since the SPST is inversely proportional to the enzyme concentration. The results of SPST test on ten hospitalized patients, in which cases all the three myelogenous leukocytes, i.e., neutrophils, monocytes and eosinophils were observed, are given in Table 4. The mean cellular peroxidase (MCP) of these cells were $(8.18 \pm 4.08) \times 10^{-8} \gamma$ of $\mathrm{HRP}$ in neutrophils, $(4.97 \pm 2.72) \times 10^{-8} \gamma$ of HRP in monocytes and $(15.29 \pm 3.71) \times 10^{-8} \gamma$ of $\mathrm{HRP}$ in eosinophils, respectively.

\section{DISCUSSIONS}

The clinical studies of Sato-Sekiya's peroxidase stain has been reviewed by Sato. ${ }^{26}$ The present SPST method can be a new approach for further studies, by the use of Sato-Sekiya's stain, on the clinical problems concerning peroxidase of blood leukocytes. Hitherto, there is a paucity of literature dealing with the quantitative determination of peroxidase activity of blood leukocytes. Schultz and Kaminker ${ }^{30}$ determined the peroxidase content in gravimetric units of myeloperoxidase of the normal human leukocytes. Arakawa and Katsushima ${ }^{14,15}$ have reported new methods for colorimetric estimation of peroxidase in serum or plasma and for that of blood leukocytes. By the latter, the peroxidase content per single myeloid cell in the peripheral blood can, they state, be estimated, but one must be careful in reading the data because peroxidase activity varies greatly 
TABLE 4. SPSTs and peroxidase content in

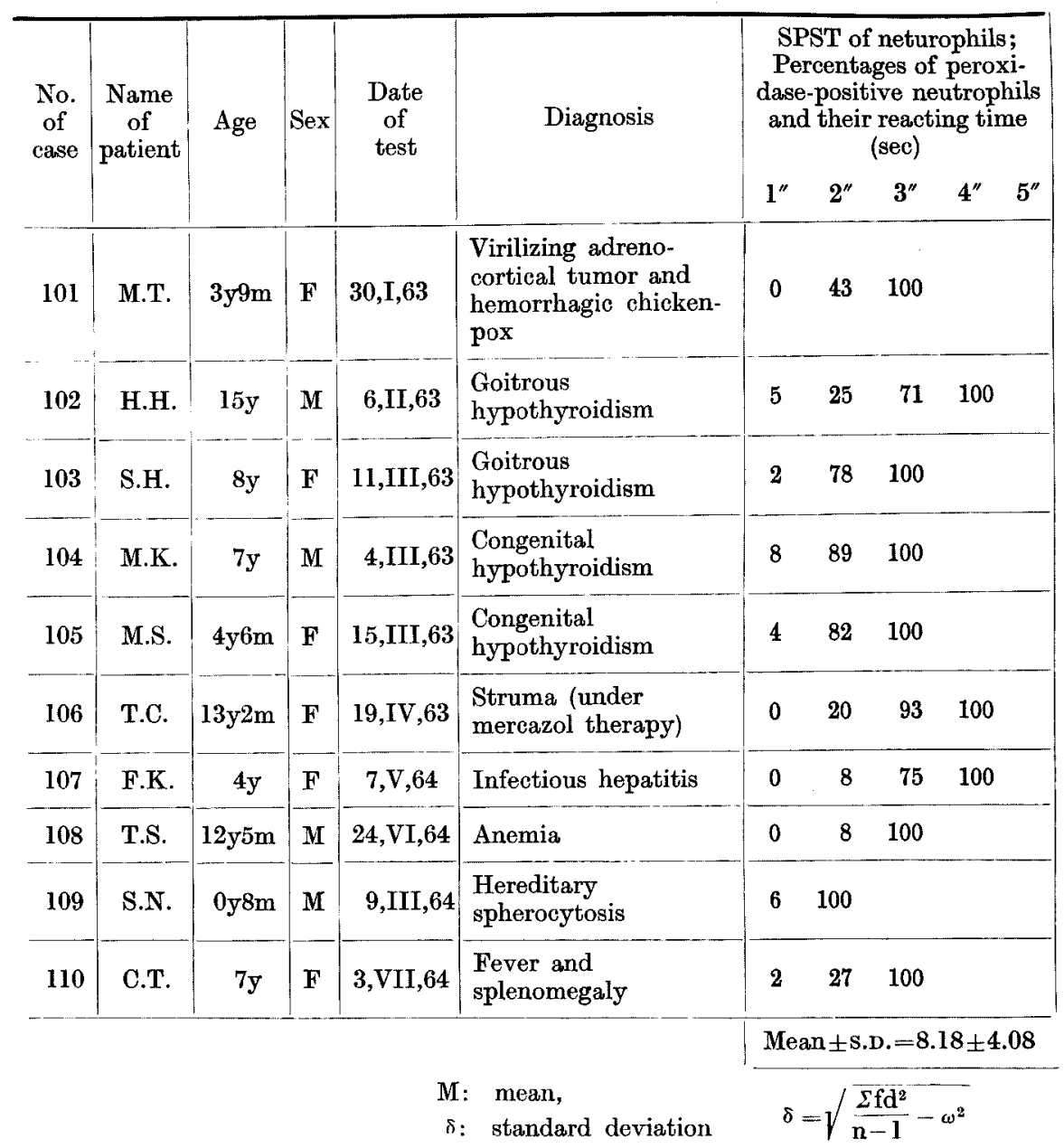

according to the kind of myeloid leukocytes as was shown by the present author (ef. Fig. 2 and Table 4). A comparison of these different assay methods is shown in Table 5 (ef. Table 5).

In Table 4, the MCP of neutrophils, monocytes and eosinophils showed a considerable variations among cases. The reason why such variations of MCP occur remains to be studied.

Myeloperoxidase was isolated from leukocytes or chloroma tissue by Agner ${ }^{1,2}$ and Schultz. ${ }^{29}$ The mechanism of enzyme action of peroxidase was studied in detail by Chance. ${ }^{5}$ Methods of peroxidase assays were reviewed by Maehly. ${ }^{20}$ The present SPST method is useful in a clinical assay of the overall activity of 
neutrophils, eosinophils and monocytes

\begin{tabular}{|c|c|c|c|c|}
\hline \multirow{2}{*}{$\begin{array}{c}\text { MCP } \\
\text { of } \\
\text { neutrophils, } \\
\left(\times 10^{-8} \gamma \text { of }\right. \\
\text { HRP })\end{array}$} & $\begin{array}{l}\text { SPST of monocytes; } \\
\text { Percentages of peroxidase- } \\
\text { positive monocytes and } \\
\text { their reacting time (sec) }\end{array}$ & $\begin{array}{c}\text { MCP } \\
\text { of } \\
\text { monocytes }^{*} \\
\left(\times 10^{-8} \gamma \text { of }\right.\end{array}$ & $\begin{array}{c}\begin{array}{c}\text { SPST } \\
\text { of } \\
\text { esoinophils } \\
\text { (sec) }\end{array} \\
\end{array}$ & \multirow{2}{*}{$\begin{array}{c}\text { MCP } \\
\text { of } \\
\text { eosinophils } \\
\left(\times 10^{-8} \gamma \text { of }\right. \\
\text { HRP })\end{array}$} \\
\hline & $1^{\prime \prime} 2^{\prime \prime} 3^{\prime \prime} 4^{\prime \prime} 5^{\prime \prime} 6^{\prime \prime} 7^{\prime \prime} 8^{\prime \prime} 9^{\prime \prime} 10^{\prime \prime}$ & HRP) & $1^{\prime \prime} 2^{\prime \prime} 3^{\prime \prime}$ & \\
\hline 7.79 & $\begin{array}{llllll}0 & 15 & 83 & 90 & 92 & 95\end{array}$ & 6.45 or less & $\begin{array}{lll}48 & 95 & 100\end{array}$ & 15.96 \\
\hline 6.80 & $\begin{array}{lllllllll}0 & 9 & 25 & 41 & 51 & 71 & 84 & 89 & 91\end{array}$ & 3.82 or less & $91 \quad 96 \quad 100$ & 21.23 \\
\hline 9.60 & $\begin{array}{lllllllll}0 & 2 & 38 & 64 & 76 & 76 & 90 & 94 & 94\end{array}$ & 4.19 or less & 46100 & 15.94 \\
\hline 10.83 & 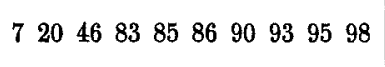 & 6.21 or less & 7498 & $\begin{array}{c}19.52 \\
\text { or less }\end{array}$ \\
\hline 10.04 & 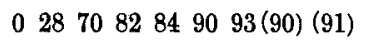 & 6.69 or less & 58100 & 17.40 \\
\hline 6.56 & $\begin{array}{llllllll}0 & 2 & 17 & 72 & 78 & 84 & 88 & 94\end{array}$ & 3.51 or less & $25 \quad 78 \quad 100$ & 12.39 \\
\hline 5.54 & $0 \quad 0154060-83--85$ & 2.95 or less & 36100 & 14.72 \\
\hline 6.21 & $05638191-9394-95$ & 5.04 or less & $5 \quad 43100$ & 8.39 \\
\hline 11.08 & $\begin{array}{llllllll}4 & 8 & 16 & 34 & 46 & 56 & 56 & 64\end{array}$ & 4.84 or less & 18100 & 12.54 \\
\hline 7.31 & 013729496 & 6.03 or less & 37100 & 14.85 \\
\hline \multicolumn{3}{|c|}{ Mean \pm S.D. $=4.97 \pm 2.72$} & \multicolumn{2}{|c|}{ Mean \pm S.D. $=15.29 \pm 3.71$} \\
\hline
\end{tabular}

* The maximum positivity of monocytes was not determined in the present series of cases.

peroxidase contained in blood neutrophils, eosinophils and monocytes, respectively.

Chance ${ }^{5}$ stated that the peroxidase had an activity towards ferrocytochrome $c$ and that inasmuch as peroxidase was specific for ferrocytochrome $c$ and could participate in intracellular coupled oxidations, this enzyme could provide an auxilliary path for biological oxidations. According to Klebanoff, ${ }^{17-19}$ a number of substances of biological importance, i.e., reduced diphosphopyridine nucleotide, reduced triphosphopyridine nucleotide, ferrocytochrome c, epinephrine, norepinephrine, uric acid, thyroxine and ascorbic acid, can be oxidized by the peroxidase system. According to Sato and his group, ${ }^{26,34,35,37}$ methylglyoxal which may occur in cases of $B_{1}$ avitaminosis has an inhibitory effect on the peroxidase 
TABLE 5. The comparison of different peroxidase assay methods of blood leukocytes

\begin{tabular}{|c|c|c|c|c|c|}
\hline Authors & $\begin{array}{c}1963 \\
\text { Katsushima } \\
\text { Ko,16 }\end{array}$ & $\begin{array}{c}1962 \\
\text { Schultz }\end{array}$ & \multicolumn{3}{|c|}{$\begin{array}{c}1965 \\
\text { Present author }\end{array}$} \\
\hline $\begin{array}{c}\text { Peroxidase } \\
\text { Activity }\end{array}$ & $\begin{array}{c}5.53<10^{-8} \gamma \text { of } \\
\mathrm{HRP} / \text { cell }\end{array}$ & $\begin{array}{c}7.1 \times 10^{-6} \gamma \text { of } \\
\mathrm{MPO} / \mathrm{cell}\end{array}$ & $\begin{array}{c}(15.29 \pm 3.71) \\
\times 10^{-8} \gamma \text { of } \\
H R P / \text { cell }\end{array}$ & $\begin{array}{c}(8.18 \pm 4.08) \\
\times 10^{-8} \gamma \text { of } \\
\text { HRP } / \text { cell }\end{array}$ & $\begin{array}{c}(4.97 \pm 2.72) \\
\times 10^{-8} \gamma \text { of } \\
\text { HRP } / \text { cell }\end{array}$ \\
\hline $\begin{array}{l}\text { Kinds of } \\
\text { leukocytes }\end{array}$ & $\begin{array}{c}\text { Average of all } \\
\text { myeloic } \\
\text { leukocytes }\end{array}$ & $\begin{array}{l}\text { Average of all } \\
\text { leukocytes }\end{array}$ & Eosinophils & Neutrophils & Monocytes \\
\hline $\begin{array}{l}\text { Method of } \\
\text { observation }\end{array}$ & $\begin{array}{l}\text { Spectrophoto- } \\
\text { metry }\end{array}$ & $\begin{array}{l}\text { Spectrophoto- } \\
\text { metry }\end{array}$ & \multicolumn{3}{|c|}{ Microscopic observation } \\
\hline Materials & $\begin{array}{l}\text { Leukocyte } \\
\text { suspension }\end{array}$ & $\begin{array}{l}\text { Leukocyte } \\
\text { homogenate }\end{array}$ & \multicolumn{3}{|c|}{ Blood smear } \\
\hline $\begin{array}{l}\text { Substrate } \\
\text { and } \\
\text { H donors }\end{array}$ & $\begin{array}{c}\mathrm{H}_{2} \mathrm{O}_{2} \\
\text { Benzidine } \\
\alpha \text {-Naphthol }\end{array}$ & $\begin{array}{c}\mathrm{H}_{2} \mathrm{O}_{2} \\
\text { Guaiacol }\end{array}$ & \multicolumn{3}{|c|}{$\underset{\text { Benzidine }}{\mathrm{H}_{2} \mathrm{O}_{2}}$} \\
\hline $\begin{array}{l}\text { Reaction } \\
\text { time }\end{array}$ & (30 minutes) & $\begin{array}{c}\text { short } \\
\text { (seconds) }\end{array}$ & \multicolumn{3}{|c|}{$\begin{array}{c}\text { short } \\
\text { (seconds) }\end{array}$} \\
\hline
\end{tabular}

reaction of both leukocytes and milk. A prolongation of the SPST of blood neutrophils in cases of beriberi is corrected by the administration of vitamin $B_{1}$. Thus many factors may play roles in the utilization of peroxidase. Various iron enzymes in iron deficiency have been studied by Beutler, ${ }^{4}$ Gubler ${ }^{9}$ and Dallman. ${ }^{8}$ Peroxidase is a hemoprotein and so iron should be essential in biosynthesis of this enzyme. Therefore, it is reasonable to think that iron might play an important part in the occurrence of variations of SPST and MCP of neutrophils, monocytes and eosinophils, respectively. In this connection, further studies on SPST and MCP of these cells remain to be desired.

The problems of 'peroxidase-negative neutrophils' were discussed by Sato, Arakawa and others in a recent issue of this journal..$^{3,13,27}$ The present author reported, in 1954, a qualitative abnormity of the peroxidase granules of myelogenous leukocytes, 'the congenital gigantism of peroxidase granules' ${ }^{12}$ It would be very interesting to use the present method to see if any quantitative, as well as qualitative, abnormity of peroxidase by way of SPST and MCP might be encountered in such a disease.

\section{Acknowledgment}

The author is grateful to Drs. H. Wako, and Ts. Arakawa for their kind advices and to the late Dr. A. Sato, Professor Emeritus of Tohoku University, for his suggestions. 


\section{References}

1) Agner, K. Verdoperoxidase, a ferment isolated from leukocytes. Acta Physiol. Scand., 1941, II, Suppl. VIII, 3-62.

2) Agner, K. Cristalline myeloperoxidase. Acta chem. scand., 1958, 12, 89-94.

3) Arakawa, Ts., Wada, Y., Hayashi, T., Kakizaki, R., Chida, N., Chiba, R., Konno, T. \& Shioura, H. Uracil-uric refractory anemia with peroxidase negative neutrophils. Tohoku J. exp. Med., 1965, 87, 52-76.

4) Beutler, E. \& Blaisdell, R.K. Iron enzymes in iron deficiency, V. Succinic dehydrogenase in rat liver, kidney and heart. Blood, 1960, 15, 30-35.

5) Chance, B. A symposium of the mechanism of enzyme action, ed. by MeElroy and Glass, B., The Johns Hopkins Press, 1954, pp. 399-460.

6) Chiba, M. Short-timed peroxidase reaction of blood leucocytes of B-avitaminotic pigeons, 39th Report of the Peroxidase Reaction. Tohoku J. exp. Med., 1932, 19, $282-295$.

7) Chiba, M. Prolongation of short-timed peroxidase reaction of leucocytes as a sign of avitaminosis B and effect of vitamin B on it, A clinical experiment, 4lst Report of the Peroxidase Reaction. Tohoku J. exp. Med., 1932, 19, 486-512.

8) Dallman, P.R. \& Schwartz, H.C. Cytochrome $c$ and myoglobin in iron-deficient rats. Pediatrics, $1965,35,677-686$.

9) Gubler, C., Cartwright, G.E. \& Wintrobe, M.M. Studies on copper metabolism. XX. Enzyme activities and iron metabolism in copper and iron deficiencies. $J$. biol. Chem., 1957, 224, 533-546.

10) Heilmeyer, L. \& Begemann, H. Blut und Blutkrankheiten, Handbuch der inneren Medizin, vierte Auflage, zweiter Band, Springer-Verlag, Berlin, Göttingen, Heidelberg, 1951, p. 549.

11) Higashi, O. 'Peroxidase response' of erythron in anemia. Tohoku J. exp. Med., $1953,58,327-343$.

12) Higashi, $O$. Congenital gigantism of peroxidase granules, the first case ever reported of qualitative abnormity of peroxidase. Tohoku $J$. exp. Med., 1954, 59, 315-332.

13) Higashi, O., Katsuyama, N. \& Satodate, R. A case with hematological abnormality characterized by the absence of peroxidase activity in blood polymorphonuclear leukocytes. Tohoku J. exp. Med., 1965, 87, 77-93.

14) Katsushima, N. \& Arakawa, Ts. A method for colorimetric estimation of peroxidase in serum or plasma. Tohoku $J$. exp. Med., 1961, 75, 238-242.

15) Katsushima, N. A method for quantitative estimation of leukocyte peroxidase in peripheral blood. Tohoku J. exp. Med., 1963, 78, 339-346.

16) Katsushima, N. Peroxidase content in single myeloid cell and in plasma - Its clinical significance in pediatrics. Tohoku $J$. exp. Med., 1963, 79, 250-266.

17) Klebanoff, S.J. An effect of thyroxine and related compounds of the oxidation of certain hydrogen donors by the peroxidase system. $J$. biol. Chem., 1959, 234, 24372442 .

18) Klebanoff, S.J. An effect of thyroxine on the oxidation of reduced pyridine nucelotides by the peroxidase system. J. biol. Chem., 1959, 234, 2480-2485.

19) Klebanoff, S.J. Reduced pyridine nucelotides as activators of certain reactions catalized by peroxidase. Biochim. Biophys. Acta, 1960, 44, 501-509.

20) Maehly, A.C. Methods of biochemical analysis, ed. by Glick, D., Interscience Publisher Inc., New York, 1954, 1, 381-408.

21) Sato, A. \& Sekiya, S. A simple method for differentiation of myeloic and lymphatic leucocytes of the human blood, A New Peroxidase Reaction. Tohoku Igaku Zassi (Jap.), 1922, 6, 534-541.

22) Sato, A. \& Yoshimatsu, Sh. The peroxidase reaction in epidemic encephalitis. A 
new diagnostic and prognostic method. Amer. J. Dis. Child., 1925, 29, 301-312.

23) Sato, A. The localization of a lesion in the brain by differential staining of blood smears. Amer. J. Dis. Child., 1925, 29, 313-317.

24) Sato, A. \& Sekiya, S. A simple method for differentiation of myeloic and lymphatic leucocytes of the humah blood. A New Peroxidase Reaction (Copper Method). Tohoku J. exp. Med., 1926, 7, 111-115.

25) Sato, A. \& Shoji, K. Counting chamber peroxidase method for blood. Simultaneous rapid differential leucocyte count and total leucocyte count. J. Lab. clin. Med., 1928, 13, 1058-1060.

26) Sato, A. Three unexpected products of peroxidase reaction: brain site of lesion, beriberi poison and new disease. Tohoku J. exp. Med., 1964, 83, 103-113.

27) Sato, A. Peroxidase-negative neutrophils in Arakawa-Higashi's syndrome, in encephalitis Economo, further in 'Healthy Brethren'. Tohoku J. exp. Med., 1965, 87, $94-100$.

28) Schulten, H. Lehrbuch der klinitchen Hematologie, Georg Thieme Verlag, Leipzig, 1939 , p. 69 , p. 427.

29) Schultz, J. Myeloperoxidase. Ann. N.Y. Acad. Sci., 1958, 75, 22-30.

30) Schultz, J. \& Kaminker, K. Myeloperoxidase of the leucocyte of normal human blood. I. Content and localization. Arch. Biochem. Biophys., 1962, 96, 465-467.

31) Suzuki, K. \& Arakawa, T. 'Aperoxidatic' milk as a possibly early symptom of avitaminosis-B. An experimental study, 34th Report of the Peroxidare Reaction. Tohoku J. exp. Med., 1930, 16, 228-231.

32) Suzuki, K. Copper peroxidase reaction with shortened stain time in different diseases of children. Tohoku J. exp. Med., 1932, 19, 262-268.

33) Suzuki, T. Further study on the short-timed peroxidase reaction of blood leucocytes; prolongation of the reaction in avitaminosis B, 44th Report of the Peroxidase Reaction. Tohoku J. exp. Med., 1934, 23, 23-45.

34) Suzuki, T. An experimental study on the short-timed peroxidase reaction of blood polymorphonuclears of rice-diseased mice. The prolongation of the shortest peroxidase stain-time as an early sign of B-avitaminosis and the mechanism of the prolongation in question, 55th Report of the Peroxidase Reaction. Tohoku J. exp. Med., 1935, 25, 201-217.

35) Suzuki, T. Effect of urines of lactants on leucocyte peroxidase; a relation between leucocyte peroxidase and B-avitaminotic urine, 57th Report of the Peroxidase Reaction. Tohoku J. exp. Med., 1935, 25, 575-587.

36) Tivey, H., Li, J.G. \& Osgood, E.E. The average volume of leukemic leukocytes. Blood, 1951, 6, 1013-1020.

37) Wako, H. The isolation and identification of methyl glyoxal, (pyruvaldehyde or pyruvic aldehyde) from human milk. Part III. Identification of acetaldehyde and methylglyoxal from human milk by paper partition chromatography, 265th Report of the Peroxidase Reaction (212th Human Milk Study). Tohoku J. exp. Med., 1953, 57, 191-197.

38) Wintrobe, M.M. Clinical Hematology, fifth edition, Lea and Febiger, Philadelphia, 1962 , p. 411. 